\title{
Blood Intimacies and Biodicy: Keeping Faith with Ticks
}

\author{
James Hatley \\ 'The high mountains are for wild goats; \\ the crags a refuge for rock-badgers'. \\ Psalm 104 \\ 'Ye ugly, blastit, creepin, wonner' \\ Robert Burns, 'To a Louse' \\ 'Couldn't ticks be just a little extinct?' \\ Tom Horton
}

\section{A Landscape of Ticks}

To walk the forests of my native Montana in the months of April and May is to be welcomed into a landscape chock full of ticks. As one sets foot among the bunch grasses thriving on a south-facing mountain slope of Palouse Prairie, it is best if one's arms are fully clothed with a long-sleeve shirt and one's haunches with snugly-belted pants tucked definitively into the socks. In the exuberance of greenery after the winter snows, scores of ticks are waiting at every turn to make a temporary home in one's very flesh. Stripping down to greet a warm sunbeam is a perilous act. Stopping under a ponderosa pine, particularly as a passing spring breeze shakes its needled branches, can set off a barely audible pattering emanating from one's clothing, hair and skin, as wood ticks, Dermecentor andersoni, sprinkle down on oneself from above. And the results can be anything from vaguely irritating to alarmingly personal to outright deadly. Rocky Mountain Spotted Fever, Rickettsia rickettsii, which infects one to three percent of the ticks a Montanan encounters (Damrow) and is only one of the diseases of which the tick is a vector, once inflicted a death rate of $20 \%$ on infected humans in these natural environs. Early treatment with antibiotics has reduced this to $5 \%$ (Petri). A rate of attrition, even if it is a highly reduced one, afflicts Montanans who insist on venturing into the woods. And in that regard, certainly more lives are lost to the elements, the weathers and diseases spread by assorted arthropods than to the bared fangs of the charismatic and endangered mega-fauna for which the state is justly famous. More than grizzly 
bears or mountain lions, the ticks of spring threaten human incursions into the wild and mark our sense of the living world as a place that is not so friendly to us after all.

Although Tick Fever has been mentioned in an Egyptian papyrus as early as 1550 BCE, it was only in 1893 that science compellingly linked a tick bite to a tick disease (Anderson 205). But even if a tick bite were not potentially infectious, it is still stomach-turning. For in the tick's approach we humans become unwilling hosts, offering our very blood for its food and our all-too-human flesh for its temporary home. In scientific lingo, John Anderson reports, ticks are 'obligate, bloodsucking, non-permanent, ectoparasitic arthropods' with a taste for mammals, birds and reptiles. In their quest for food, ticks ingest 'enormous quantities of ... blood, lymph or digested tissues' (Anderson 205). Further, Anderson notes, a tick cannot moult or reproduce without first feeding on its host. We humans, then, are not only important to the day-to-day sustenance ${ }^{1}$ of this or that tick but also necessary to its future generations. Our skin and blood, it could be argued, are external appendages of the tick's own body, unwilling but still necessary organs in carrying out the tick's reproductive processes. In a manner of speaking, we are an ad hoc womb or placenta for ticks, as we provide nutriment not only necessary for the fertilization and laying of their eggs but also for the development of their progeny, with the help of later feedings, into mature organisms. No wonder then that the discussion of the eeriness of ticks even has a philosophical pedigree: Cato, Aristotle and Pliny have all referred to ticks as disgusting. And ticks make an appearance in no less a classical text than Homer (Anderson 205).

\section{Taking Tick Extinction Seriously?}

What difference, then, would it make if the two genera of ticks, or at least a good number of their respective species, were to go extinct? More provocatively put, wouldn't it actually be better, at least in many cases, if ticks were actually to become extinct? In animals such as these, we perhaps meet the limit case of any discourse that would characterize the extinction of a species as one of the unmitigated moral evils of our time. Certainly, Job should have included ticks in his litany of complaints to the most high concerning the evils visited upon humans in the created world. It is hard to imagine the wisdom in any patience we might be called upon to exercise regarding the existence of ticks.

1 Keeping in mind that the day-to-day sustenance of a tick occurs as the result of only one or two feedings during its lifetime. 


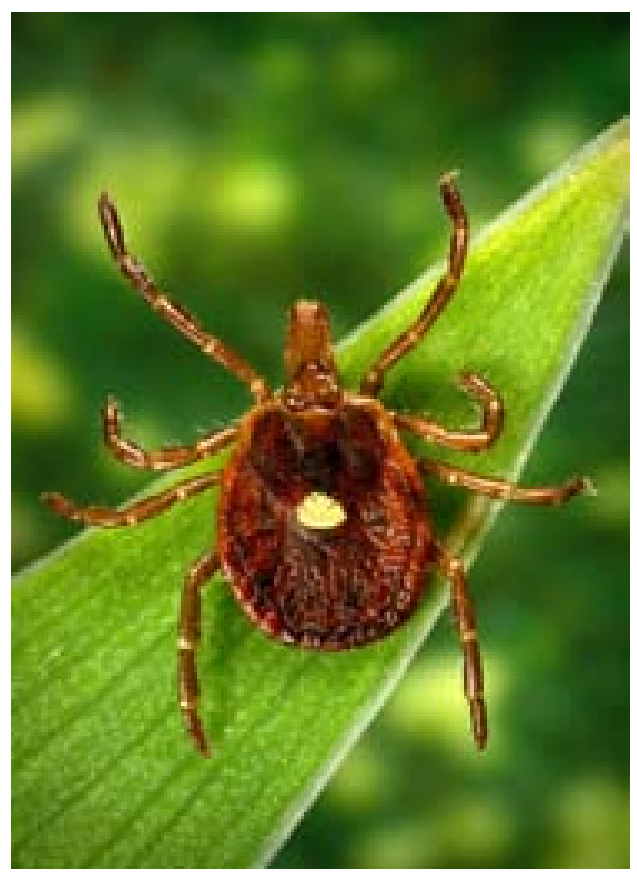

Dorsal view of a female 'lone star tick', Amblyomma americanum.

Credit: Image in the public domain. Courtesy of CDC/ Dr. Amanda Loftis, Dr. William Nicholson, Dr. Will Reeves, Dr. Chris Paddock

One factor in our attitude toward ticks involves their place in the tree of life. Even if the Almighty has exhibited an inordinate fondness for beetles and all the rest of the arthropods in creating so many of them, humans very often do not share this feeling. Although arthropods comprise $72 \%$ of all animal species on earth, they are not nearly so well represented on lists of endangered species (Black et. al. 364). And of those arthropods that are represented, a large number consist of bees, ants, butterflies and moths. Although criticized in 2003 for not including a broad range of endangered parasites (Whiteman et. al.), by 2009 the International Union for Conservation of Nature Red List of Threatened Species still does not contain a single species of tick or mite. A zoomorphic bigotry is at play here. The seemingly alien morphology of insects and their immediate kin-compound eyes, multiple pairs of legs, an exoskeleton in lieu of skin and a thorax that breathes - makes it difficult for mammalian humans to accept them as fellow creatures. And the arthropods, more than any other family of flora or fauna, regularly put into question our very hold upon our mortal existence through a variety of stings and bites, all too often venomous or infectious. Not to mention that in their boring and tunnelling and feeding, whether accomplished by individuals or colonies or swarms, they attack not only our own bodies but our homes and gardens too, doing so with a greater efficiency and effect than 
any mammal. It is perhaps no wonder that we humans have shown a distinct preference for worrying about the futures of species with whom we share a less threatening and more obvious kinship.

What words then, even if they might not be praise, might be offered on behalf of ticks? One argument against the desirability of a particular tick species' extinction is that its demise would go hand in hand with the extinction of its host. As Durden and Keirans put it, 'Host extinction also results in co-extinction in nature of all associated host-specific parasites' (Durden et al.). ${ }^{2}$ Given that around four times as many parasitic species as free-living ones exist on earth, then the extinction of any of the free-living is likely to be doubled or tripled in its eventual impact on biodiversity. Thus, as each lunged and chordate creature succumbs to extinction, a species of tick is likely to go down with it, or, at the very least, find its continued survival in greater question. ${ }^{3}$ From this perspective, our fighting against the extinction of ticks is merely a corollary to our fighting against the extinction of the animal upon which the tick feeds. ${ }^{4}$ Yet within this perspective another moral quandary emerges. In one case, that of the endangered gopher tortoise (Gopherus polyphemus), ticks are being carefully picked off of individuals of the host species in order to enable the latter to remain healthy before being re-released into what is already a stressful environment. The case of the African rhinoceros is even more dramatic, involving four tick species specifically dependent upon their host and specifically targeted by conservationists for removal. One of these ticks - Amblyomma personatumis already close to extinction. If this is the case, it would appear to be a step forward in the host organism's evasion of its own demise. ${ }^{5}$ Who could be upset by this?

Given our own very human and very hostile attitude toward tick bites and tickrelated diseases, even to discuss one's qualms about the extinction of ticks seems a ludicrous, pointless and perhaps hypocritical exercise. While, like the common cold, ticks will likely always be with us, worrying about the extinction of this or that particular species arguably deflects our all too flighty attentiveness from the real concerns we should be exercising for all the flora and fauna surrounding us that do not so insistently feed upon us and yet are all too quickly being lost to the newly emerging Anthropocene world. Perhaps it would be just as well if we included only the free-living organisms in our ongoing fight to maintain a modicum of biodiversity on the planet and forget altogether the parasites.

\footnotetext{
2 See also Koh et al.

3 A distinction needs to be made between ticks who are generalists and ticks who are specialists in feeding on their host(s). The former group may actually become more abundant as habitat loss continues, although the particular circumstances of this abundance are also ecologically objectionable.

4 Some ticks are more opportunistic than others and would be able to switch hosts over the long run. And ticks that specifically feed on humans are hopefully the most likely to survive in the Anthropocene.

5 There is at least one paper focusing on the possible extinction of a specific tick: Miller et al.
} 
On the other hand, several ecological factors weigh in against dismissing the possible extinction of tick species. First, ticks have co-evolved with their host species. Just as more charismatic predators benefit their prey populations by ferreting out weakened animals, ticks have been documented as specifically attacking, at least in one case, weakened deer (Bolte et al.). And there are some indications that parasites generally 'exert selective pressures on host populations and are at least partially responsible for maintaining higher levels of genetic diversity when compared to non-parasitized animals' (Durden et al. 99). Further, even if ticks exert selective pressure on endangered species, in the act of doing so they become an important food for yet other species. Durden and Keirans mention a meeting held in 1991 at a conference in Kruger National Park, South Africa, to address the increasing scarcity of some tick species such as, for example, the ticks mentioned above that feed on rhinoceroses but, as it turns out, in turn are fed on by oxpeckers and other tick-eating birds (Miller et al. 90). Finally, the very qualities that make ticks such efficient parasites mean that they are a potentially rich source of pharmacological substances (Miller et. al., 90). As in so many issues facing environmental thinkers, the plight of ticks in a time of extinction proves to be a series of trade-offs as the complexity of the ecological systems in which they are embedded resists any simple analysis or reading. What kills us also keeps us alive. This is the unavoidable insight of any thinker who would take seriously the abysmally, even if richly interdependent relationships constituting the living world.

\section{Biodicy in lieu of Theodicy in the Book of Job}

But beyond either biocentric or anthropocentric arguments for the survival of tick species, another factor calls for attention. Regardless of whether the overall benefit derived from the existence of ticks outweighs that which would occur in their extinction, the question of whether we are called to have faith in ticks can also be raised. This likely is an odd question for the reader - for what do ticks have to do with faith ${ }^{6}$ and faith with ticks? In response, one can note that the significance of affirmation as a human response to the living world is no small matter. And in the case of ticks, our willingness to affirm the living world

6 The discussion of faith here is not informed by the Greek pistis, which, as used by Paul, came to imply a belief in and commitment to a specifying content, a doxa about Christ, achieved through a moment of conversion. In lieu of pistis, the faith in question here is like that which Buber finds in the Hebrew emunah, a faith in which fidelity to and trust in another is already in play before any specifying content to that faith can be given to justify one's commitment. Buber argues that Christ's approach to faith is that of emunah, while Paul's is not (See Buber, 7-11, 28-29). The issue remains of how this theological term, which is normally used to characterize a relationship with the Transcendent, can be applied to one with another finite creature, particularly a tick. As the discussion in the essay makes clear, faith in the tick is required precisely in the context in which I find the capacity of the tick to live in its Umwelt transcends my own capacity to account for this lived existence in terms of my Welt or world. The tick, as simple as its life might appear to me, is not reducible to my conception of that life. Indeed, my very conception of the tick is already a betrayal of it. 
is sorely put to the test. Allied with theodicy, with a consideration of whether humans can affirm the creation of the world with all its unjustifiable suffering, is the question of what could be termed 'biodicy'. Is it really a good thing to be a biological entity? At the edges of any talk about the living world, particularly in Western culture, lies great ambivalence concerning the conditions of our embodiment. For to exist as a human entails that one exists as a mortal and abject body that only comes into itself from out of yet other bodies - initially in its birth and later in its constant search for nutrition. Put more trenchantly, to exist is to live, and to live is not only to be born and give birth to a succeeding generation but also to feed upon others. A corollary to our human insistence on ingesting other living entities in order to grow into the fullness of our years is that yet other living entities, whether they be bear, tick or flesh-eating bacterium, have similar designs on us.

The queasiness over our having been born is not a new experience. No less a figure than Job begins his complaint against the Most High with a thorough and graphic rejection of his own birth:

Let the stars of the twilight thereof be dark; let it look for light, but have none; neither let it behold the eyelids of the morning;

Because it shut not up the doors of my mother's womb, nor hid trouble from mine eyes.

Why died I not from the womb? Why did I not perish at birth?

Why did the knees receive me? And wherefore the breasts, that I should suck? (Job 3: 9-12)

Some might argue that Job's cursing of the day of his birth simply expresses his outrage at the injustice of suffering the loss of his children, his flocks, his home and his health, even as the watchful eye of the Creator, the Most High, looks on. But the carefully-developed metaphors of Job's complaint hint at yet another dimension to his suffering: that to be born is to be rendered abject, that Job's humanity only comes to him as a groping from out of the womb of his mother's body to her knees spread open to receive him. The very intimacy of one's tie to the maternal body that has conceived one is an uncanny rejoinder to any sense of autonomy one might muster on one's own behalf. And the Most High, in his eventual response to Job, speaks expansively and pointedly of the womb: 'Who shut up the sea with doors, when it broke forth, and issued out of the womb?'7 (Job 38: 8). And again, a few lines later: 'Hath the rain a father? Or who hath begotten the drops of dew? Out of whose womb ${ }^{8}$ came the ice?

7 In the Hebrew, rachem.

8 In the Hebrew, beten, literally 'belly', and by implication, 'womb'. The more formal word for womb, 'rachem', is used in conjunction with the ice and, as the footnote above indicates, the sea. The two words- 
And the hoar-frost of heaven, who hath gendered ${ }^{9}$ it?' (Job 38: 28-29). Both of these passages suggest how being born of a womb is a characteristic shared by all living and elemental entities, even as the emergence of the elemental into existence, particularly in the case of the waters, challenges the very thought of a biological womb. ${ }^{10}$ The birth, which is to say, the creation of the elemental is pointedly not to be confused with that of human beings or animals. Further, the questions on the part of the Tetragrammaton to Job are phrased in such a way that the male Job, who has no womb at all, is put at a disadvantage to the Most High who hints obliquely and ironically of maternity as well as paternity in regard to all creatures and elements. In these questions, the metaphysical and creative implications of the womb outstrip Job's own all-too-human interest in and understanding of his own birth as a creature. An abysmal decentering of the very question of Job's natality, ${ }^{11}$ of his having come to be born, is effected in the perspective offered on creaturely existence by the Most High.

But the demonstration is not finished. Turning to animal mothers, the Tetragrammaton asks Job to consider, among other creatures, the vulture:

She dwelleth and abideth on the rock, upon the crag of the rock, and the stronghold.

From thence she spieth out the prey; her eyes behold it afar off.

Her young ones also suck up blood; and where the slain are, there is she. (Job 39: 27-30) ${ }^{12}$

beten and rachem are used in conjunction with one another in key passages in both the Book of Job and Psalms. In the passage at the beginning of Job, in which he curses the day he was born, both terms are used and are both translated in the JPS version as 'womb'.

9 In the Hebrew, yeladu, from yelad, to give birth.

10 The mysteriousness of the waters in their fructification of the earth is given extended discussion in Genesis Rabbah XIII: 9-15.

11 One should keep in mind that the Latin term natura is etymologically related to giving birth, to bearing forth a world.

12 The International Standard Bible Encyclopedia discusses in its entry on 'Vulture' a smaller variety of the species found in the Biblical Near East called 'Pharaoh's Chicken' (Stratton-Porter). Members of this species 'were protected by a death penalty for their value as scavengers in cities. They fed on carcasses of animals that killed each other, ate putrid fish under the nests of pelican and cormorant, followed caravans across the desert, and were ready for offal thrown from animals dressed for feasting. They flocked over the altars for the entrails from sacrifice, and devoured scraps cast aside by tent-dwellers and residents of cities. They paired with affectionate courting and nested in crevices, in walls, hollow trees and on cliffs. They raised only one pair of young to the season, as the nestlings were over two months old before they took wing' (Stratton-Porter). Perhaps due to this latter trait, at least one Hebrew word for vulture- MGX/rchm - is the same as the root for 'compassion', which in turn also is related to that for 'womb'. The particular vulture denoted by racham, Strong's Hebrew Lexicon notes, is 'supposed to be tender to its young' (SH7360). This belief is evidently shared by the Egyptians as well. Horapollo, in his treatise on Egyptian hieroglyphs comments: 'It [the glyph for the vulture] symbolises also a compassionate person, which appears to some to be the furthest from its nature, inasmuch as it is a creature that preys upon all things; but they were induced to use it as a symbol for this, because in the 120 days, during which it brings up its offspring, it flies to no great distance, but is solely 
The Most High's affirmation of birth and motherhood, framed in zoomorphic rather than anthropomorphic terms, is even more scandalous, more probing of the justice of biological existence, than Job's own initial rejection of his birth. While Job poses the issue of justice in terms of theodicy - 'Why must I be born into senseless suffering in a world created by a just G-d?' - the Most High answers it in terms of biodicy - 'Behold, the vulture!' Further, this answer provides not a justification for biological existence but an unconditional affirmation of its uncanniness, ${ }^{13}$ awkwardness, abjection. Later, in carrying this argument to its most logical extreme, the Most High proclaims: 'Behold, Behemoth'. After this proclamation, the Tetragrammaton taunts, Job asking him:

Will he [Behemoth] make a covenant with thee, that thou shouldest take him for a servant forever?

Wilt thou play with him as with a bird? Or wilt thou bind him for thy maidens? (Job 40: 28-29)

Obviously in the eyes of the Most High, neither Job nor any other human being will ever bring Behemoth, whose name is curiously also the plural form in Hebrew of 'animal' or' beast', to bay.

\section{The Love of Kin}

Many ethical, social and political issues follow in the wake of the tick bite, particularly now in that renewal and likewise desolation of earth that is termed Anthropocene. Where ticks are found the significance not only of my vulnerability but also of that of my fellow humans to being fed upon by another species is raised. In tropical climates removed from my own temperate world (though no longer so distantly as prior to the Anthropocene), ticks and their fellow arthropods can justifiably be characterized as a scourge of humanity, persistent vectors of a host of fatal and crippling diseases. And these diseases only threaten to become more widespread as global warming progresses. Paradoxically, the environmental degradation being undergone in the Anthropocene leads not simply to a crisis of extinction but also to one of overabundance. The ranges of some ticks, as well as other disease-bearing arthropods, are now spreading north and south into formerly less hospitable climates. As a result, to term maladies such as Rocky Mountain Spotted Fever or Crimean-Congo Hemorrhagic Fever as merely tick-borne is increasingly a sleight

\footnotetext{
engaged about its young and their sustenance; and if during this period it should be without food to give its young, it opens its own thigh, and suffers its offspring to partake of the blood, that they may not perish from want of nourishment' (Horapollo 26).

13 Keeping in mind that the German and so Freudian term for this word - unheimlich - makes the point more clearly how one is not at home in one's very skin, in one's coming to oneself through the womb of one's mother.
} 
of hand; these diseases are just as surely human-borne given our complicity in global warming. Our discourse needs to develop a greater sensitivity to the complexity of the natural world in which we are currently playing willy-nilly an increasingly formative role.

In various manners, then, the emerging world of the Anthropocene is reverberating into the Umwelt of ticks. Should this matter to us? On the one hand, we must not forget our fellow humans who suffer and even die from the many infections brought about by ticks. The distribution of diseases and mortal suffering in a time of human-induced climate change is no small matter. On the other hand, the question remains, however peculiar and marginal, of whether and how we humans should have faith in ticks, unloved and unwanted as they might be in our day-to-day existence. Even if ticks are a bane to humanity, might we not also be asked to have some degree of faith in their existence? To witness the simultaneous necessity of these two thoughts - the tick as invitation to faith and as affliction - is to undergo the ambivalence of biodicy, an ambivalence that is rooted in the very abyss from out of which creation emerges, the whirlwind from out of which the Tetragrammaton addresses humanity.

On a less theological note, one might consider the question of who should be numbered among our biological kin as a corollary to the question of whether we should have faith in ticks. Evolutionary and genetic science have made clear that our own roots in the living world are deeply intertwined with all biota, from archaic anaerobic bacteria to protozoa to fruit flies to great apes. But beyond this objectively-conceived account of our relationship with other living entities lies an ethico-phenomenological one-how should we live our relationship with this co-evolved and living world? Another way of putting this latter question is to ask how we are called to witness a more-than-human living world, as opposed to simply knowing about it. Ticks, as off-putting as they might be, insist on our acknowledging in our very flesh the depth and uncanniness of our relatedness to them and, by implication, to all other living beings. Ticks in particular do not allow our retreat into merely knowing about them. In their insistence in feeding upon us we are reminded palpably and undeniably of how we are ultimately co-evolved relatives. They would not be able to digest us so handily otherwise.

My being a potential host to a tick then is not a matter of my choice, although my decision as to how to comport myself in regard to the tick's investment in my flesh is indeed mercifully left to me. Nevertheless, I cannot help but participate, by my very embodiment as human, as Homo sapiens, in the hunger of the tick, not to mention the mothering of its next generation. This involvement has already occurred before I could have ever assented to it as a condition for my birth into existence, even if in the aftermath of this involvement I would evade being actively subjected to being fed on, given the opportunity for doing so. 
At the very least, submitting to the inevitability of the tick's hunger is a condition for my entrance into the spring landscape of a Montanan forest. If that forest is to remain wild, which is to say, dynamically alive and open to the full range of evolved relationships constituting Cenezoic existence, then I am called to refrain from altering this landscape in such a manner that ticks, along with any of the other species indigenous to it, would simply be eradicated from it. Leopold's insight about the importance of the mountain lion to the mountain deserves a timely extension. To have faith in a mountainside of Palouse Prairie, dotted with bitterroots, shooting stars and anemones, as well as home to bunch grass and grazing deer, requires as a corollary my faith in ticks, my affirming their participation in this particular and unique instantiation of the living world.

'Behold, the tick!' In these words I address my fellow humans and, if I am a believer of a particular sort, I hear as well the address of the Creator of all that exists. Yet how might I also address this newborn faith in ticks to the ticks themselves? In a subject filled with odd thoughts and impossible questions, this may be the oddest and most impossible of all. But the humour implicit in the question's very asking is in fact its very point. The Umwelt, the world environing the tick, is radically incongruent with my human world, my Welt, and yet we, the tick and I, are nevertheless intimately interwoven, entangled ${ }^{14}$ with one another. In beholding the tick's investment in me, I behold how my flesh is sensed and signified anew through the tick's Umwelt in a manner that transcends, which is to say, differs incompossibly, from my own sense of my flesh as its emerges in my understanding of world. The tick senses me and behaves in regard to me in a manner that is beyond any imaginable justification, if he or she and I were to share the world as humans do. And yet, from within my imagination of the tick's Umwelt, its quest for my blood is already affirmed. Simply to imagine a tick as animate, I must already have placed my faith in it or her or him and so in its sense of how to nourish itself. ${ }^{15}$

Caught between my Welt and the tick's Umwelt, I might now venture a mode of address to her or him or it ${ }^{16}$ that is permeated with paradox and comedy: 'my relationship with you, dear tick, leaves me in irresolvable ambivalence in regard to you'. The tick, of course, does not understand my words, but in my speaking them to it I encounter burrowed within me an alter ego, a tick-like self, that hears sympathetically my address on behalf of the tick, even as I register our adversarial nature in that other part of me that remembers all too well my fragile hold on my mortality and my vulnerability to the tick bite. In this expressive

14 I am deeply thankful for Deborah Bird Rose's development of this particular modality of the ethical in her Reports from a Wild Country: Ethics for Decolonisation: 'Simply to listen is to be drawn into a world of ethical encounter: to hear is to witness; to witness is to become entangled' (Rose, 213).

15 Is this not as well the point made by The Most High to Job in the speech from out of the whirlwind?

16 Keeping in mind, it is born without sexual organs! 
evocation of the tick, I engage in an act of mindfulness suggested by MerleauPonty, such that my thinking is no longer alone with itself but must 'witness' how another 'is born in its body'. This other whom I witness 'does not empty me ... is not a haemorrhage of my 'consciousness', but redoubles me with an alter ego' (Merleau-Ponty 233). In standing in for the tick, my thinking becomes redoubled, loyal to both my human perspective and that of a tick. Speaking thus to the tick engenders comedy precisely by the contradiction, the impossibility of reasonably assuming these two viewpoints, these two loyalties, simultaneously. But, miraculously, by my bringing the tick's hunger playfully into my human language, laughter is inspired. ${ }^{17}$ Borrowing the words of Robert Burns in his poem 'To a Louse', I can say, for instance: 'Oh it's you again, dear tick, “ye ugly, blastit, creepin, wonner"'. The 'dear' here certainly comes dearly but still with a spark of humour, if I keep in mind the insurmountable equivocation involved in this impossible and yet still meaningful address. ${ }^{18}$

But even more provocatively, beyond cultivating humour about the tick's very hunger for my flesh, I am called to have faith in this hunger. For it is no less than a necessary condition for the evolution and so emergence into the living world of all creatures of flesh and so too of my very embodiment as human. To lose faith in the tick and its hunger for me is to lose faith in the fabric of our co-evolved existences. Abandoning faith in the tick in this manner would be tantamount to my abandoning faith in the living world itself. This latter choice is simply not possible for humans, although our actions in the Anthropocene have been in part fuelled by delusions of managing our own evolution, as if this prospect were something we could accomplish without already having inherited an immense legacy for which we are indebted to millions of generations of manifold species of living entities who have led the way to our own birth as a species.

In comic book fantasies, we might imagine ourselves as self-created, as perfectly autonomous brains downloadable into one or another variety of an indestructible and mechanistic body through which the world around us will be put thoroughly at our will's disposal. But the tick's hunger for our all-tooedible flesh reminds us insistently that the very birth of the human species and so of our embodiment as humans necessarily entails a vulnerability to all other

17 I am particularly indebted in the formulation of this paragraph to my colleague Timothy Stock, who in an unpublished paper argues for an understanding of philosophy as a phenomenology and semiology of the comic, which is to say, of sustained ambivalence or contradiction (Stock).

18 An important caveat: the laughter involved here can only occur at my expense. To laugh at the plight of a fellow human suffering from a tick bite, particularly if she or he suffers infection on its account, is a blasphemy of the human. One moves from witnessing the tick in one's own vulnerability to being its host, to offering the flesh of others to the tick for the sake of one's own laughter. This is no longer comedy but instead mockery. 
life. Happily, yet mortally, I am a creature and not a god or an automaton. And happily I find myself born into existence amidst other creatures who in turn are neither gods nor automatons.

Rather, they are kin. Holmes Rolston III in his essay 'Values gone Wild' argues for our developing the virtue of sympatry, a mindfulness of and openness to our biological kin in all the dimensions of relation they afford. While many indigenous cultures are adept at fostering this virtue, our contemporary civilization, the one currently engaged in replacing the Cenezoic achievement with the Anthropocene, is most often clumsy and unimaginative in its understanding of what sympatry involves, if this virtue is even acknowledged. While the tick does not inspire the erotic love of desire and union that more charismatic species - dolphin, wolf, rose, wallaby-might, ticks are after all kin. And being more carefully attentive to the qualities of heart and mind involved in the love of kin, no matter how distant they might be, would serve us humans well in approaching the unloved others, these species all too easily neglected in a time of extinction, among which can be counted the humble, even if blasphemous tick.

James Hatley is Professor of Philosophy at Salisbury University, USA. Working across issues in ethics, literature, environmental philosophy and Jewish studies, he is the author or editor of several books, including Suffering Witness: The Quandary of Responsibility after the Irreparable (2000).

\section{Works Cited}

Anderson, John F. 'The Natural History of Ticks.' Medical Clinics of North America 86.2 (2002): 205-217.

Black, Scott Hoffman and D. Mace Vaughan. 'Endangered Insects.' The Encyclopedia of Insects. Ed. Vincent Resh and Ring Carde. San Diego, CA: Academic Press, 2003. 364.

Bolte, J.R., J.A. Hair and J. Fletcher. 'Whitetailed Deer Mortality following Tissue Destruction induced by Lone Star Ticks.' Journal of Wildlife Management 34 (1970): 546-552.

Buber, Martin. Two Types of Faith. Trans. Norman Goldhawk. New York: Collier Books, 1951.

Damrow, Todd. 'Tick Borne Diseases in Montana.' <http://ipm.montana.edu/ YardGarden/docs/ticks-insect.htm $>$ Accessed 28 Feb. 2011.

Durden, Lance and James Keirans. 'Host-Parasite Coextinction and the Plight of Tick Conservation.' American Entomologist 42 (1996): 87-91. 
Horapollo. Hieroglyphics of Horapollo Nilous. Trans. Alexander Cory. London: William Pickering, 1840. <http://sacred-texts.com/egy/hh/hh013.htm>. Accessed 3 Mar. 2011.

International Union for Conservation of Nature and Natural Resources. The IUCN Red List of Threatened Species. <http://www.redlist.org > Accessed 3 Mar. 2011.

Genesis Rabbah. Ed. and trans. Rabbi Dr. H. L. Friedman. London: Soncino Press, 1983.

Koh, Lian Pin, Robert R. Dunn, Navjot S. Sodhi, Robert K. Colwell, Heather C. Proctor, Vincent S. Smith. 'Species Coextinctions and the Biodiversity Crisis.' Science 305 (2004): 1632-34.

Merleau-Ponty, Maurice. The Visible and the Invisible. Trans. Alphonso Lingis. Evanston: Northwestern UP, 1968.

Miller, Hillary, Allis Conrad, Stephen Barker and Charles Daugherty. 'Distribution and phylogenetic analyses of an endangered tick, Amblyomma spenodonti.' New Zealand Journal of Zoology 34 (2007): 97-105.

Petri, William. 'Rocky Mountain Spotted Fever.' The Merck Manuals Online Medical Library. <http://www.merckmanuals.com/home/secl7/ch195/ ch195b.html> Accessed 3 Mar. 2011.

Rolston III, Holmes. 'Values Gone Wild.' Inquiry 26 (1983): 181-207.

Rose, Deborah Bird. Reports from a Wild Country: Ethics for Decolonisation. Sydney: U of New South Wales P, 2004.

Stock, Timothy. 'In Other Words, Amphibology is a Funny Thing to Say.' Session 4C, 'On the Comic.' University of Toronto: North American Levinas Society Annual Conference, 1 September 2009.

Stratton-Porter, Gene. 'Vulture.' International Standard Bible Encyclopedia $<$ http://www.searchgodsword.org/enc/isb/view.cgi?number=T9105> Accessed 3 Mar. 2011.

Strong, James. A Concise Dictionary of the Words in the Hebrew Bible. Madison, N.J.: James Strong, 1890. <http://www.heraldmag.org/olb/contents/ dictionaries/SHebrew.pdf> Accessed 3 Mar. 2011.

Whiteman, Noah Kerness and Patricia G. Parker. 'Using parasites to infer host population history: a new rationale for parasite conservation.' Animal Conservation 8 (2005): 175-181. 